\title{
WYBRANE ASPEKTY HANDLU MIĘDZYNARODOWEGO NA PRZYKŁADZIE POLSKI I NIEMIEC
}

Z a r y s t r e ś c i: Handel międzynarodowy stanowi ważny aspekt we współczesnej gospodarce światowej. Liberalizację handlu oraz postęp technologiczny zaliczać należy do ważniejszych czynników mających wpływ na wzrost dynamiki handlu międzynarodowego. Polski handel zagraniczny wykazuje relatywnie silną koncentrację wokół niewielu państw partnerskich, bez wątpienia jednak najważniejszym partnerem handlowych w zakresie eksportu i importu są Niemcy.

Celem niniejszego opracowania jest analiza ważniejszych aspektów handlu międzynarodowego z uwzględnieniem jego miejsca we współczesnej gospodarce. Autor przedstawi czynniki determinujące rozwój handlu międzynarodowego, zwróci również uwagę na współczesne koncepcje handlu zagranicznego.

S ł o w a k 1 u c z o w e: handel międzynarodowy, Unia Europejska, eksport, Niemcy

K 1 a s y f i k a j a J E L: L 21; N10

\section{WSTĘP}

Handel międzynarodowy odgrywa istotną rolę w nowoczesnej gospodarce. Nie podlega wątpliwości, iż problematyka handlu międzynarodowego jest jednym $\mathrm{z}$ najważniejszych fundamentów współczesnych procesów internacjonalizacji i globalizacji. Wśród podstawowych czynników przyczyniających się do wyraźnego wzrostu znaczenia handlu

\footnotetext{
* Adres do korespondencji: Robert Rogaczewski, Państwowa Wyższa Szkoła Zawodowa w Koninie, Katedra Finansów i Logistyki, ul. Przyjaźni 1, 62-510 Konin, e-mail: r.rogaczewski@ gmail.com;
} 
międzynarodowego w gospodarce światowej wyróżnia się liberalizację handlu oraz postęp technologiczny. Celem niniejszego opracowania jest analiza ważniejszych aspektów handlu międzynarodowego we współczesnej gospodarce. Uwagę poświęcono również czynnikom wpływającym na rozwój handlu międzynarodowego oraz wymianie handlowej pomiędzy Polską i Niemcami.

\section{ZNACZENIE HANDLU MIĘDZYNARODOWEGO WE WSPÓŁCZESNEJ GOSPODARCE}

Polityka wymiany międzynarodowej ukształtowała się na gruncie historycznego procesu rozwoju teorii i praktyki handlu międzynarodowego [Rymarczyk, 2010, s. 53]. Handel międzynarodowy w swojej podstawowej formie istniał już w czasach starożytnych. Jego dynamiczny rozwój przypada na przełom XVIII i XIX wieku, w którym to efekty rewolucji przemysłowej w Anglii i innych krajach Zachodniej Europy umożliwiły obniżenie kosztów wytwarzania czy rozwoju transportu. Przewaga konkurencyjna tych krajów, które jako pierwsze potrafiły wykorzystać pozytywy wynikające z rewolucji przemysłowej i produkcji maszynowej, przyczyniła się do ukształtowania międzynarodowego podziału pracy. Oznacza to, iż kraje uprzemysłowione dostarczały produkty przemysłowe, a pozostałe wszelkiego rodzaju surowce.

Ważnym aspektem dalszej analizy jest wskazanie na różnice znaczeniowe pomiędzy „handlem międzynarodowym” a „handlem zagranicznym”. Zasadniczą różnicą jest to, iż handel zagraniczny obejmuje wymianę handlową dwóch krajów $\mathrm{z}$ punktu widzenia jednego $\mathrm{z}$ nich, natomiast handel międzynarodowy sugeruje spojrzenie na taką samą wymianę handlową i na jej rezultaty z punktu widzenia obu tych krajów łącznie [Foltyński, 1970, s. 20].

Handel międzynarodowy umożliwia wykorzystanie większej ilości czynników wytwórczych, większą produkcję oraz konsumpcję dóbr i usług. Abstrahując od tego, jakie miejsce dany kraj zajmuje w międzynarodowym podziale pracy, wymiana międzynarodowa stanowi w dzisiejszych czasach istotny element systemu ekonomicznego każdej gospodarki narodowej. Wymiana towarowa obejmuje przede wszystkim obroty towarowe i usługowe, a więc eksport (sprzedaż za granicę dóbr i usług wytworzonych w kraju) oraz import (zakup wyprodukowanych za granicą dóbr i usług).

Cechą handlu międzynarodowego jest jego odpłatny charakter w procesie wymiany towarów i usług przez podmioty danego kraju z partnerami mającymi siedzibę za granicą. $Z$ tego też tytułu należy zwrócić uwagę na istotne kwestie, a mianowicie [Dudziński, 2010, s. 11]: 
- na transakcyjność dwustronną (świadczenia towarowe i świadczenia wzajemne),

- na różnorodność pomiędzy charakterem transakcji (transakcja handlu zagranicznego i wewnętrznego),

- oraz na zakres przedmiotowy.

Wzasadzie transakcjerealizowanewUEzewzględunawewnątrzwspólnotową wymianę dóbr i usług można określić jako realizowane $\mathrm{w}$ ramach rynku wewnętrznego, natomiast $\mathrm{w}$ ujęciu teoretycznym wymiana między podmiotami z krajów członkowskich nadal mieści się w kanonie handlu zagranicznego, ponieważ przesłanka wynikająca z ogólnej definicji (kontrahenci pochodzący z różnych krajów) została spełniona. Potwierdzają tą tezę przede wszystkim publikacje statystyczne, które klasyfikują obroty pomiędzy poszczególnymi krajami UE jako handel zagraniczny. Handel zagraniczny obejmuje $\mathrm{w}$ formie uproszczonej dwa podstawowe rodzaje obrotów, $\mathrm{tj}$. eksport $\mathrm{i}$ import. Jako eksport rozumieć należy zbyt wyprodukowanych $\mathrm{w}$ danym obszarze gospodarczym towarów i usług do obcych obszarów gospodarczych. Prostymi słowy należy rozumieć go jako sprzedaż towarów i usług za granicę [CzechWinkelmann, 2008, s. 215]. Import natomiast określa się jako wprowadzanie towarów i usług $\mathrm{z}$ innych obszarów gospodarczych, tzn. $\mathrm{z}$ zagranicy. W przypadku eksportu przepływ strumieni produktów i usług następuje w relacji kraj - zagranica, w imporcie natomiast kierunek ten jest odwrotny. Zarówno eksport, jak i import mogą przybierać w handlu międzynarodowym różnorodne formy. Coraz częściej w praktyce gospodarczej, nie tylko zagranicznych, ale również polskich przedsiębiorstw wyróżnia się obroty widzialne, a więc towary oraz obroty niewidzialne, nazywane usługami [Dudziński, 2010, s. 15].

Warto zwrócić uwagę na głównych uczestników handlu międzynarodowego. Do znaczących „graczy” na rynku globalnym zaliczyć należy państwa UE, Chiny oraz Stany Zjednoczone.

Analizując wartości eksportu i importu poszczególnych państw warto zwrócić uwagę, iż w przypadku krajów UE i Chin obserwuje się nadwyżkę eksportu nad importem. Tendencja odwrotna jest w przypadku Stanów Zjednoczonych.

Dane statystyczne dotyczące handlu międzynarodowego towarami umożliwiajądokonaniepomiaruwartościiilościtowarów.Biorącpoduwagęhandel w ramach UE należy wyróżnić handel wewnątrzunijny (realizowany pomiędzy państwami UE) i handel zewnętrzny (realizowany przez państwa UE z innymi krajami). 
Wykres 1. Ważniejsze podmioty handlu międzynarodowego w 2014 r. w mld EUR 2000

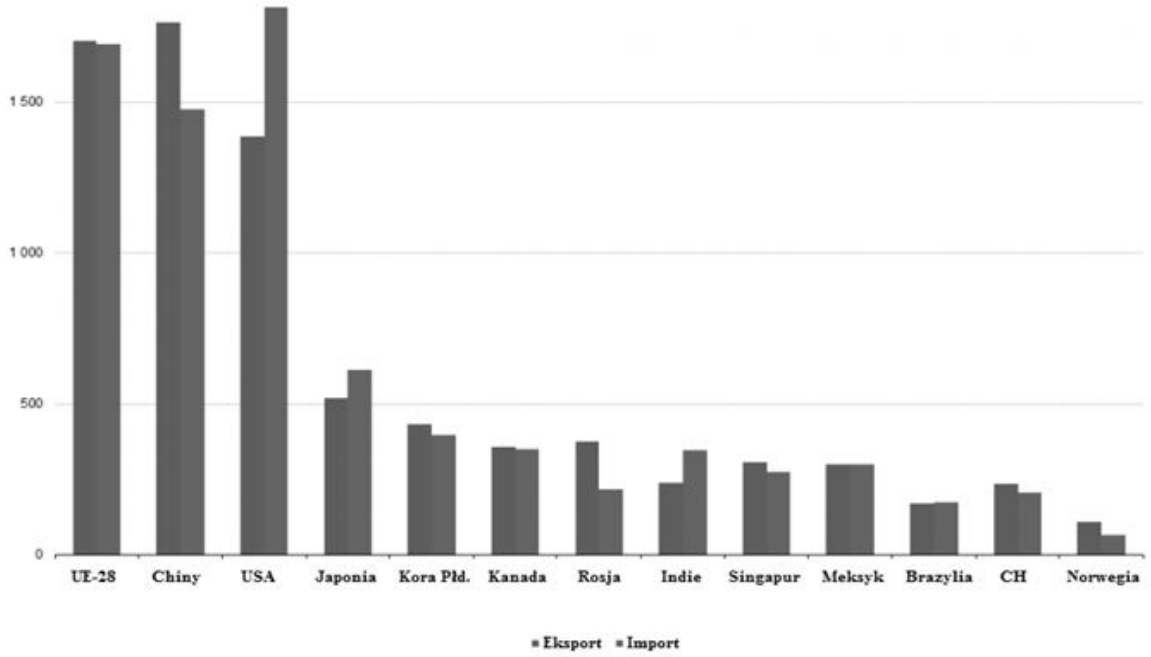

Źródło: (Eurostat 2014, pobrano z http://ec.europa.eu)

Wykres 2. Ważniejsi partnerzy handlowi w zakresie eksportu i importu zewnętrznego krajów UE w 2015 r.
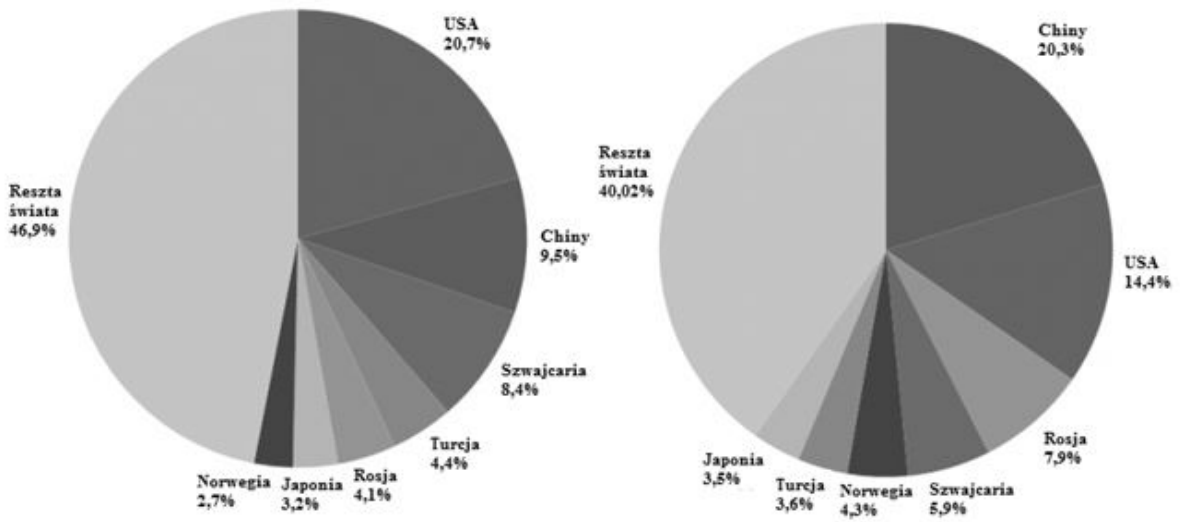

Źródło: (Eurostat 2015, pobrano z http://ec.europa.eu) 
Warto zwrócić uwagę na udział procentowy krajów UE w imporcie i eksporcie zewnętrznym (wykres 2). Dane dotyczące eksportu i importu odnoszą się wyłącznie do eksportu i importu UE. Największym odbiorcą towarów eksportowanych w UE w 2015 r. były Stany Zjednoczone. Eksport w ramach handlu zewnętrznego do USA wynosił $20,7 \%$ całkowitej wielkości eksportu. Chiny i Szwajcaria były kolejnymi co do ważności rynkami docelowymi dla eksportu UE. Eksport do tych krajów wyniósł kolejno 9,5\% i 8,4\% całkowitego eksportu w handlu zewnętrznym UE. Siedem największych importerów - Chiny, Stany Zjednoczone, Rosja, Szwajcaria, Norwegia, Turcja i Japonia - wypracowało ponad połowę łącznej wartości eksportu towarów z UE, co stanowiło 53,1\%. W przypadku handlu importowego krajów UE wyżej wymienione państwa były największymi dostawcami towarów do UE. Państwa te miały większy udział $\mathrm{w}$ imporcie towarów z UE niż wynosił ich udział w eksporcie towarów do UE.

Ważną formą działań w wymianie międzynarodowej stanowi handel tranzytowy, który dotyczy obrotu towarowego. Wymiana między eksporterem a importerem odbywa się za pośrednictwem firmy tranzytowej, której siedziba znajduje się innym kraju niż eksporter czy importer [Schulze, 2008, s. 166]. Obroty towarowe i usługowe zaliczane są do najbardziej tradycyjnych i podstawowych typów stosunków wymiennych z zagranicą, natomiast eksport i import określany jest jako handel międzynarodowy [Drozdowska-Jantoń, 2004, s. 38-39].

Wśród przedmiotów wymiany międzynarodowej w literaturze przedmiotu wyróżnia się kapitał, przemysłowe dobra niematerialne oraz siłę roboczą. Międzynarodowe przepływy kapitałowe obejmują przepływy majątkowe (występujące w postaci inwestycji portfelowych, kapitału publicznego w formie pomocy bezzwrotnej oraz prywatnych inwestycji zagranicznych) i przepływy kredytowe. Te ostatnie mogą przybierać postać kredytów prywatnych, rządowych i organizacji międzynarodowych. Kolejnym z przedmiotów wymiany międzynarodowej jest migracja siły roboczej. Ma ona miejsce wówczas, gdy dokonywana jest zmiana miejsca pobytu w celach zarobkowych na okres czasu nie krótszy aniżeli jeden rok [Dudziński, 2010, s. 12-14]. Ostatnim aspektem wymiany międzynarodowej są obroty niematerialnymi dobrami przemysłowymi. Zaliczyć można do nich przepływ technologii, usługi doradztwa technicznoekonomicznego, współpracę przemysłową, obrót znakami towarowymi czy nawet przepływ dóbr chronionych prawem autorskim. 


\section{CZYNNIKI DETERMINUJĄCE ROZWÓJ HANDLU MIĘDZYNARODOWEGO}

Jedną z przewodnich cech charakterystycznych dla współczesnej gospodarki światowej jest wysoka dynamika handlu międzynarodowego, która w ciągu ostatnich lat rozwijała się znacznie szybciej niż światowe PKB. Wśród podstawowych czynników wpływających na wyraźny wzrost znaczenia handlu międzynarodowego w gospodarce światowej jest liberalizacja handlu (zaliczyć należy eliminowanie barier taryfowych i pozataryfowych) jak również postęp technologiczny.

W warunkach szybko postępującej liberalizacji handlu znaczenie tracą instrumenty taryfowe i parotaryfowe polityki handlowej kraju, zyskują zaś instrumenty nietaryfowe. Do znaczącej liberalizacji dostępu do rynków skłoniły większość krajów następujące wymierne korzyści wynikające $\mathrm{z}$ handlu międzynarodowego:

- możliwość zwiększenia produkcji,

- wzrost zatrudnienia,

- dostęp do nowoczesnych technologii, surowców i produktów niedostępnych lub trudnodostępnych w danym kraju,

- obniżanie poziomu cen krajowych.

Szybki rozwój technologiczny, jaki miał miejsce w przemyśle przetwórczym, a także w sektorach związanych z transportem, telekomunikacją i informatyką, miał istotny wpływ na przyśpieszenie obrotów handlowych. Ze względu na różnorodność postępu technologicznego w danych krajach, rozwój technologii miał wpływ na dysproporcję wzrostu eksportu w różnych grupach produktowych. Eksport wyrobów przetworzonych w ostatnim czasie był w zdecydowanym stopniu większy aniżeli eksport produktów nieprzetworzonych. Inwestycje zagraniczne stały się czynnikiem stymulującym rozszerzania się postępu technologicznego.

Wyraźny wzrost korzyści w handlu zagranicznym Polski można zaobserwować z chwilą wstąpienia Polski do UE. Po 1 maja 2004 r. w handlu Polski z krajami Unii Europejskiej nastąpiły zmiany, które miały duży wpływ na coroczny wzrost handlu wewnętrznego Polski z państwami unijnymi. Do ważniejszych zmian zaliczyć należy [Michalczyk, Chrzan, 2012, s. 94-95]:

- brak konieczności dokonywania odpraw celnych importowych, eksportowych i tranzytowych,

- polska taryfa celna jest zastępowana przez taryfę celną UE, zmianie podlegają stawki celne,

- znikają dopłaty i subsydia eksportowe do towarów rolnych eksportowanych krajów UE do Polski; polscy eksporterzy uzyskują dostęp do rynku UE, 
- w handlu z UE zostają zlikwidowane liczne ograniczenia ilościowe,

- polscy eksporterzy uzyskują prawo do dopłat na równi z innymi firmami pochodzącymi w krajów unijnych.

Mimo licznych korzyści, jakie daje członkowstwo w UE, coraz częściej tworzone jest instrumentarium wspierające eksport polskich przedsiębiorstw, szczególnie MŚP ${ }^{1}$. Polityka mająca na celu wspieranie działań eksportowych traktowana jest jako ogół działań władzy państwowej, których celem jest uzyskanie maksymalnych korzyści z tytułu uczestnictwa kraju w wymianie międzynarodowej [Michalczyk, Chrzan, 2012, s. 103]. Polityka proeksportowa jestodmianą zagranicznej polityki ekonomicznej państwa. Jej celem jest włączenie się gospodarki danego kraju do międzynarodowego podziału pracy, poprawy w bilansie płatniczym czy też zwiększenie międzynarodowej konkurencyjności gospodarki [Bednarczyk, 2000, s. 17-24]. Należy zatem stwierdzić, iż w ramach polityki proeksportowej występują narzędzia z zakresu polityki handlu zagranicznego oraz narzędzia ogólnej polityki gospodarczej dedykowane dla eksporterów (środki polityki podatkowej, kredytowej czy ubezpieczeniowej). Polityka handlu międzynarodowego jest nieodzownie kojarzona ze stosowaniem określonych instrumentów i środków przy użyciu których państwo zmierza do osiągnięcia przyjętych celów gospodarczych [Rynarzewski, Zielińska-Głębocka, 2006, s. 311-312].

\section{WYMIANA HANDLOWA POLSKI I NIEMIEC}

Ze względu na geograficzne położenie państw Niemiec i Polski oraz dążenie do wspólnych interesów widoczna jest tendencja wzrostowa współpracy międzynarodowej. Gospodarcza współpraca bilateralna Polski i Niemiec rozwija się dynamicznie od pierwszej dekady XXI wieku. Wzrost współpracy miał swoje ekonomiczne apogeum z chwilą przystąpienia Polski do Unii Europejskiej. Rozszerzenie UE w 2004 r. było istotnym impulsem do wzmożonej wymiany handlowej z Niemcami.

Na podkreślenie zasługuje również fakt, iż Polska wśród krajów Grupy Wyszehradzkiej² wykazuje największą dynamikę eksportową do Niemiec. Również niemiecki eksport do państw Grupy Wyszehradzkiej uległ nasileniu, przy czym dynamika wzrostu tego eksportu do Polski była najwyższa.

Bez wątpienia wejście Polski do UE przyczyniło się do rozwoju polskiej gospodarki, o czym świadczy chociażby jej obecność wśród dziesięciu największych partnerów handlowych Niemiec.

\footnotetext{
${ }^{1}$ MŚP - małe i średnie przedsiębiorstwa

${ }^{2}$ Polska, Czechy, Słowacja, Węgry
} 
Wykres 3. Udział eksportu Niemiec do krajów Grupy Wyszehradzkiej

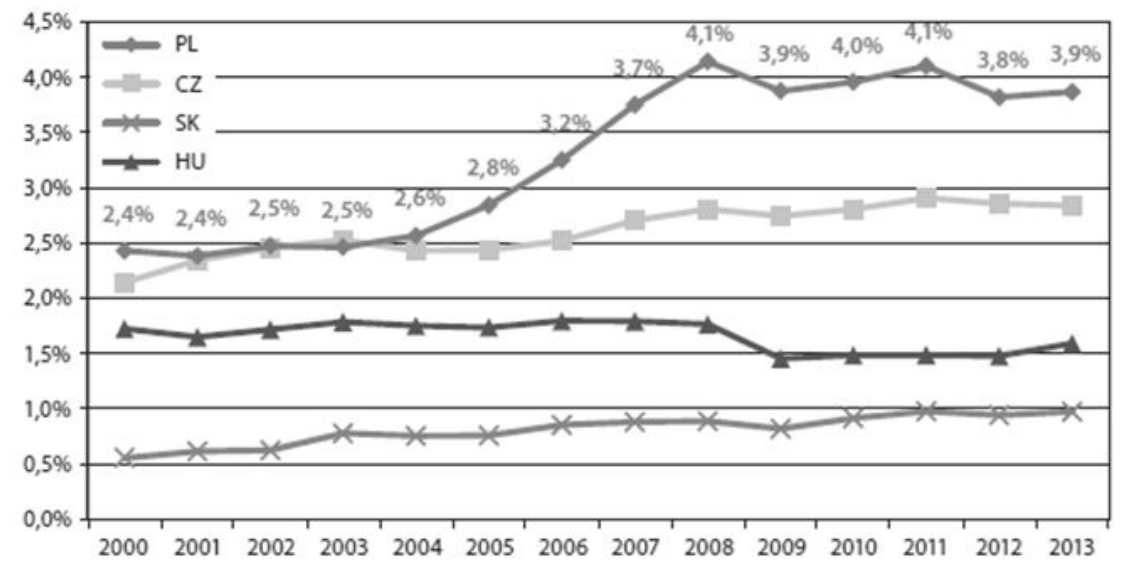

Źródło: (Statistisches Bundesamt, 2014)

W niniejszym opracowaniu analizie zostanie poddany handel polskoniemiecki z niemieckiego (w oparciu o statystyki handlu zagranicznego Niemiec) i z polskiego punku widzenia (w oparciu o polskie dane statystyczne). Dzięki analizie polsko-niemieckiego handlu zagranicznego wskazane zostaną aspekty handlu bilateralnego $\mathrm{z}$ różnych punktów widzenia.

Polski handel zagraniczny wykazuje relatywnie silną koncentrację wokół niewielu państw partnerskich. W przypadku eksportu i importu bez wątpienia najważniejszym partnerem handlowym są właśnie Niemcy (wykres 4).

Wykres 4. Wielkości importu i eksportu Polski w 2015 r.
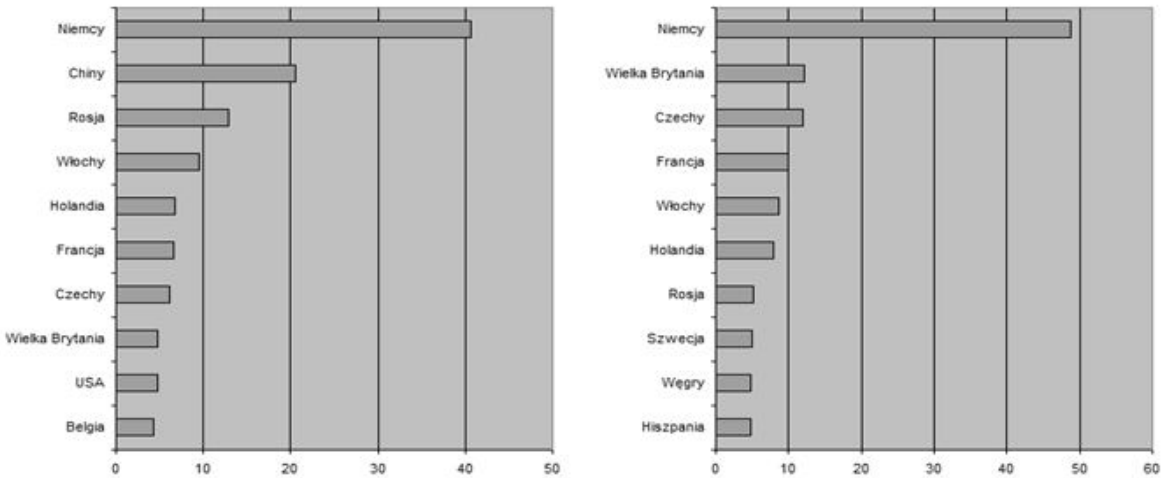

Źródło: (GUS, Departament Informacji) 
Warto zwrócić również uwagę na obroty handlowe Polski i Niemiec w latach 2000-2013. Z punktu widzenia polskiego GUS ${ }^{3}$ kształtują się one następująco:

Tabela 1. Obroty handlowe Polski i Niemiec w latach 2000-2013 według GUS

\begin{tabular}{|c|c|c|c|}
\hline \multirow{2}{*}{ Lata } & Import DE -> PL & Eksport PL > DE & Saldo \\
\cline { 2 - 4 } & \multicolumn{3}{|c|}{ w mln EUR } \\
\hline 2000 & 12690 & 11978 & -712 \\
\hline 2001 & 13427 & 13819 & 393 \\
\hline 2002 & 14220 & 14070 & -150 \\
\hline 2003 & 14721 & 15351 & 629 \\
\hline 2004 & 17397 & 17909 & 512 \\
\hline 2005 & 20024 & 20142 & 118 \\
\hline 2006 & 24202 & 23870 & -332 \\
\hline 2007 & 28948 & 26370 & -2578 \\
\hline 2008 & 32755 & 29124 & -3631 \\
\hline 2009 & 24053 & 25686 & 1632 \\
\hline 2010 & 29362 & 31427 & 2065 \\
\hline 2011 & 34042 & 35664 & 1622 \\
\hline 2012 & 32836 & 36057 & 3221 \\
\hline 2013 & 34006 & 38888 & 4882 \\
\hline
\end{tabular}

Źródło: (GUS, Departament Informacji)

Wzrost znaczenia wymiany handlowej widoczny jest w 2004 r., chociaż należy podkreślić, iż wzrost ten widoczny był już we wcześniejszych latach. W 2009 r. widoczne jest znaczące zachwianie tendencji wzrostowej, kiedy to zmniejszeniu uległa wartość polskiego eksportu do Niemiec i niemieckiego importu do Polski. Analizując saldo pomiędzy eksportem a importem można zauważyć, iż począwszy od 2009 r. Polska osiągnęła trwałą nadwyżkę obrotów handlowych z Niemcami.

Warto zwrócić uwagę na obroty handlowe pomiędzy Polską i Niemcami z płaszczyzny niemieckiego Urzędu Statystycznego, który to nieco odmiennie przedstawia wartości tych obrotów. Według poniższych danych (tabela 2) saldo pomiędzy eksportem a importem wykazuje dodatnie saldo wymiany handlowej z Polską.

\footnotetext{
${ }^{3}$ Główny Urząd Statystyczny
} 
Tabela 2. Obroty handlowe Polski i Niemiec w latach 2000-2013 według GUS

\begin{tabular}{|c|c|c|c|}
\hline \multirow{2}{*}{ Lata } & Import DE -> PL & Eksport PL -> DE & Saldo \\
\cline { 2 - 4 } & \multicolumn{3}{|c|}{ w mln EUR } \\
\hline 2000 & 14512 & 11393 & 2573 \\
\hline 2001 & 15206 & 13490 & 1716 \\
\hline 2002 & 16103 & 14193 & 1909 \\
\hline 2003 & 16362 & 15888 & 474 \\
\hline 2004 & 18776 & 15973 & 2803 \\
\hline 2005 & 22349 & 16770 & 5579 \\
\hline 2006 & 29019 & 21226 & 7793 \\
\hline 2007 & 36193 & 24055 & 12138 \\
\hline 2008 & 40750 & 25875 & 14876 \\
\hline 2009 & 31122 & 22161 & 8961 \\
\hline 2010 & 37666 & 27637 & 10029 \\
\hline 2011 & 43503 & 32305 & 11197 \\
\hline 2012 & 41823 & 33027 & 8796 \\
\hline 2013 & 42289 & 35783 & 6505 \\
\hline
\end{tabular}

Źródło: (Statistisches Bundesamt)

Zastanawiające są zatem rozbieżności pomiędzy polskimi i niemieckimi wartościami w handlu zagranicznym (wykres 5).

Wykres 5. Różnice w polsko-niemieckim handlu zagranicznym

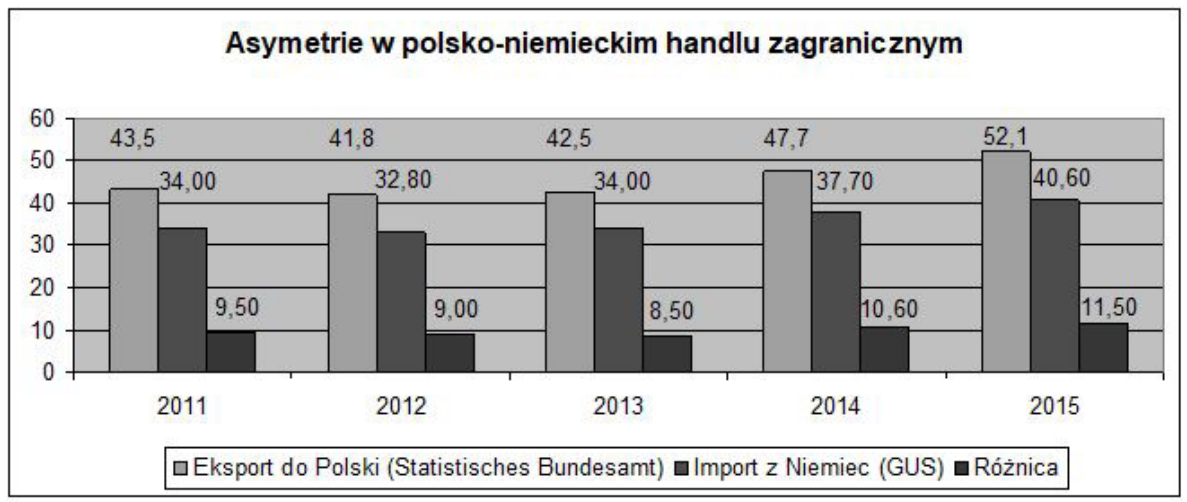

Źródło: (Statistisches Bundesamt i GUS, Departament Informacji)

Wynika to przede wszystkim z innego sposobu definiowania obrotów handlowych. Obroty z niemieckiego punktu widzenia dotyczą kraju wysyłki towaru, $\mathrm{z}$ polskiego natomiast kraju pochodzenia towarów [Wyżnikiewicz, 2014, s. 9]. 


\section{WSPÓŁCZESNE KONCEPCJE HANDLU MIĘDZYNARODOWEGO}

Tradycyjne teorie handlu międzynarodowego, których głównym elementem są przewagi komparatywne, oparte na naturalnym wyposażeniu w czynniki wytwórcze, nie thumaczą w przejrzysty sposób całej wymiany międzynarodowej, w szczególności pomiędzy krajami wysoko uprzemysłowionymi. W teorii ekonomi pojawił się nowy nurt teoretyczny, który wyjaśniał kierunki specjalizacji międzynarodowej w warunkach innych aniżeli przedstawiane przez model konkurencji doskonałej [Jantoń-Drozdowska, 2004, s 45]. Do istotnych zjawisk, które można zaobserwować w dzisiejszej wymianie międzynarodowej należą:

- zwiększenie udziału w wymianie międzynarodowej dóbr zróżnicowanych przy zmniejszającym się udziale produktów jednorodnych,

- brak konkurencji doskonałej,

- rosnący wpływ zmian technologicznych na tempo wzrostu gospodarczego.

Powyższe zjawiska warunkują rozwój handlu tzw. wewnątrzgałęziowego i mają miejsce wówczas, gdy dany kraj jednocześnie eksportuje i importuje podobne typy wyrobów. Handel wewnątrzgałęziowy dotyczy zjawiska nakładania się wektorów eksportowych i importowych, czyli dwukierunkowego transferu dóbr identycznych lub podobnych [Rynarzewski, Głębocka, 2006, s. 143]. Do nakładania się wektorów dochodzi przy wymianie produktów jednorodnych na zasadzie handlu przygranicznego czy sezonowego. Handel przygraniczny wynika głównie $\mathrm{z}$ dwóch przesłanek: zbliżonych upodobań mieszkańców strefy przygranicznej oraz kosztów transportu. Osoby, które zamieszkują strefy przygraniczne posiadają zazwyczaj podobne upodobania, dlatego chętnie wchodzą w posiadanie towarów, do których przywykli, a które łatwiej są do pozyskania $\mathrm{w}$ drugim kraju. Mowa jest tutaj o kosztach transportu, które odgrywają dużą rolę w przypadku dóbr jednorodnych.

Typowy model gospodarki wymiennej opiera się na czterech typowych współzależnościach [Krugman, Obstfeld 1997, s. 80]:

- $\quad$ współzależności pomiędzy krzywą możliwości produkcyjnych a krzywą relatywnej podaży,

- współzależności pomiędzy relatywnymi cenami a popytem,

- określaniu równowagi światowej przez światową relatywną podaż i popyt,

- wpływie terms of trade.

Wielkość i dynamika międzynarodowych obrotów handlowych, jak również profity, jakie odnoszą dane kraje $\mathrm{z}$ handlu międzynarodowego, są zależne od kształtowania się cen towarów przez nie eksportowanych i importowanych. 
Niezwykle istotne $\mathrm{z}$ punktu widzenia handlu międzynarodowego są „terms of trade", które traktowane są jako istotny, syntetyczny wskaźnik pozwalający na odzwierciedlenie kierunków i skali wpływu cen na handel zagraniczny oraz wzrost gospodarczy krajów i regionów. W literaturze przedmiotu należy wyróżnić kilka koncepcji tego wskaźnika, do których zalicza się [Świerkocki, 2004, s. 74]:

- towarowe (cenowe) terms of trade,

- wolumenowe terms of trade,

- dochodowe terms of trade.

Najczęściej wykorzystywany jest wskaźnik towarowy (cenowy) terms of trade. Towarowe terms of trade definiowane jest jako relacja zmian cen dóbr eksportowanych do zmian cen dóbr importowanych przez dane kraje [Dudziński, 2015]. Inaczej ujmując jest to ilość jednostek dobra importowanego za jednostkę dobra eksportowanego. Wzrost wskaźnika cenowego terms of trade postrzegany jest jako zjawisko pozytywne, spadek natomiast jako negatywne. Taka interpretacja znajduje uzasadnienie wówczas, gdy dany kraj jest stosunkowo mały i w związku z tym nie ma wpływu na ceny produktów na rynku światowym [Budnikowski, 2006, s. 79].

Wykres 6. Terms of trade oraz dynamika importu i eksportu Polski w latach 1995-2013

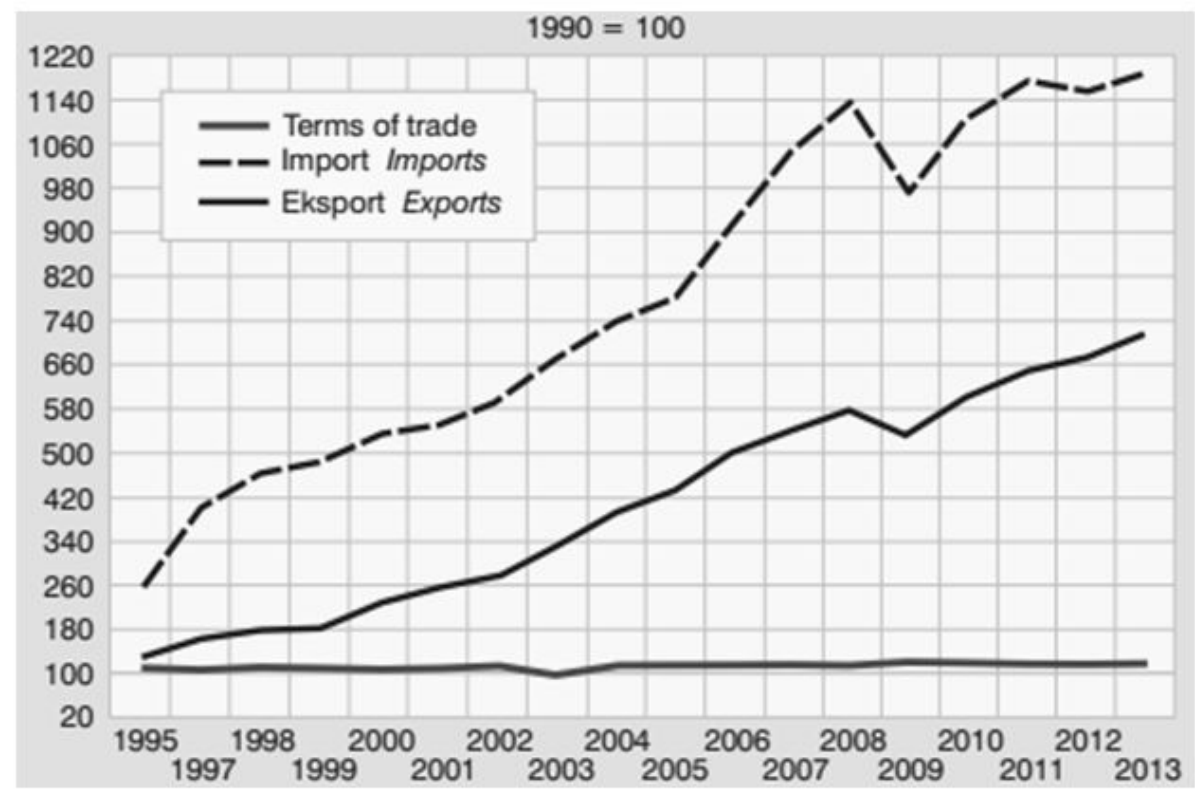

Źródło: (GUS, Departament Informacji 2014) 
Analiza warunków wymiany (terms of trade) w obrotach handlowych Polski wskazuje na korzystną tendencję względnych zmian cen eksportu i importu w latach 2001-2013. Utrzymująca się tendencja wzrostowa terms of trade może świadczyć o wzroście nowoczesności polskiej gospodarki. Jedną z przyczyn długookresowego zwiększania się terms of trade może być zmiana struktury eksportu. Podczas analizowanego okresu zwiększał się udział dóbr droższych, a więc zazwyczaj wyżej przetworzonych lub bardziej zaawansowanych pod względem technologicznym, a zmniejszaniu ulegał udział dóbr tańszych, o niższym stopniu przetworzenia lub mniej zaawansowanych technologicznie [Wyżnikiewicz, 2014].

\section{PODSUMOWANIE}

Żadna gospodarka, nawet ta znakomicie rozwinięta i wyposażona w zasoby wytwórcze, nie miałaby możliwości rozwoju w dłuższym okresie $\mathrm{w}$ izolacji, nie uczestnicząc $\mathrm{w}$ handlu międzynarodowym. Celem niniejszego opracowania była analiza ważniejszych aspektów handlu międzynarodowego z uwzględnieniem jego miejsca we współczesnej gospodarce. Uwagę zwrócono również na czynniki determinujące rozwój handlu międzynarodowego oraz na współczesne koncepcje handlu zagranicznego. Istotnym aspektem było także ukazanie rozwoju handlu międzynarodowego w Polsce na przykładzie wymiany handlowej Polski i Niemiec.

\section{LITERATURA}

Bednarczyk T., (2000), Instrumenty wspierania eksportu, kredyty i ubezpieczenia, Wydawnictwo PWN, Warszawa.

Budnikowski A., (2006), Międzynarodowe stosunki gospodarcze, Wydawnictwo PWE, Warszawa.

Chrzan M., Michalczyk W., (2012), Narzędzia regulacji w handlu zagranicznym

[w:] Rymarczyk J. (red.), Handel zagraniczny, Organizacja i technika, Wydawnictwo PWE, Warszawa.

Czech-Winkelmann S., (2008), Exportieren, kooperieren oder Direktinvestitionen

- alternative Marktstrategien [w:] Czech-Winkelmann S., Kopsch

A.(red.), Handbuch InternationalBusiness. Strategie, Praxis, Fallbeispiele, Wydawnictwo Erich Schmidt Verlag, Berlin.

Drozdowska-Jantoń E., (2004), Międzynarodowe stosunki gospodarcze, Wydawnictwo Ars boni et aequi, Poznań. 
Dudziński J., (2015), Uwagi o terms of trade we współczesnym handlu międzynarodowym [w:] Nakonieczna-Kisiel H., Gryczka M. (red.), Gospodarka regionalna i międzynarodowa - tom 1, Studia i Prace Wydziału Nauk Ekonomicznych i Zarządzania nr 41, Wydawnictwo US, Szczecin.

Dudziński J., (2010), Handel zagraniczny - zagadnienia wstępne [w:] Dudziński

J. (red.), Podstawy handlu zagranicznego, Wydawnictwo Difin, Warszawa. Foltyński Z., (1970), Teoria handlu międzynarodowego, Wydawnictwo PWN,

Warszawa.

Krugman P. R., Obstfeld M., (1997), Międzynarodowe stosunki gospodarcze, Wydawnictwo PWN, Warszawa.

Główny Urząd Statystyczny, (2014), Rocznik Handlu Zagranicznego, Warszawa. Roczniki branżowe, (2014), Rocznik Statystyczny Handlu Zagranicznego, Warszawa.

Rymarczyk J., (2010), Międzynarodowe stosunki gospodarcze, Wydawnictwo PWE, Warszawa.

Rynarzewski T., Zielińska-Głębocka A., (2006), Międzynarodowe stosunki gospodarcze. Teoria wymiany $i$ polityki handlu międzynarodowego, Wydawnictwo PWN, Warszawa.

Statistisches Bundesamt, (2014).

Szulce H., (2008), Handel zagraniczny [w:] Szulce H. (red.), Ekonomika handlu, cz. 2, Wydawnictwo WSiP, Warszawa.

Świerkocki J., (2004), Zarys międzynarodowych stosunków gospodarczych, Wydawnictwo PWE, Warszawa.

Wyżnikiewicz B., (2014), Wspótpraca gospodarcza Polska - Niemcy, Instytut Badań nad Gospodarką Rynkową, Warszawa.

\title{
SELECTED ASPECTS OF INTERNATIONAL TRADE ON THE EXAMPLE OF POLAND AND GERMANY
}

\begin{abstract}
International trade is an important aspect in present global economy. Trade liberalization and technological progress must be treated as most important factors affecting the growth rate of this kind of trade. Polish foreign trade shows a relatively high concentration around few of the partner countries, but without any doubt the most important trading partner in terms of export and import are Germany. The objective of this dissertation is to analyze selected aspects of the international trade on the example of Poland and Germany.

The purpose of this paper is to analyze the most important aspects of international trade taking into consideration its place in the modern economy. The author will present the determinants of the development of international trade, and will also draw attention to the modern concepts of foreign trade.
\end{abstract}

Keywords: international trade, export, Germany, global economy 